\title{
自己評定による筋ジストロフィーおよび 気管支喘息患児の自己意識の分析
}

\author{
小笠原 昭彦* ・甲 村 和 三** ・宮 崎 光 弘*** \\ 牛田 洋 一***.山 内 慎 吾***
}

\begin{abstract}
筋ジストロフィーおよび気管支喘息患児を对象に，自己意識についての質問紙調査を実施 した。質問紙は，自己意識・心理的ストレスに関する 42 項目と病気・入院生活についての 8 項目を加之た50項目から成る自己評定形式のものである。比較対照群は，健常な中学生・高 校生・大学生である。健常大学生群の結果の因子分析から，「情緒性」「共感性」「対人関係」

「自己信頼感」「目標志向性」の 5 因子が抽出できた。健常群に比べ, 筋ジストロフィ一群で は感情の統制面での困難さ，対人関係での消極さなどが目立った。喘息群では，感情の不安 定さ，感情統制の困難，過剩な共感性，投げやりな傾向，病気に対する「罪悪感」といった 傾向が強かった。筋ジストロフィー群よりも喘息群で, 自己意識の形成の上での問題点があ ることが示された。
\end{abstract}

キーワード：自己意識 自己評定 筋ジストロフィー 気管支喘息

\section{I 。はじめに}

病気が人に与之る影響は大きい。短期間で治癒が確 実な病気でさ之，日常行動に与之る影響は多大である。 まして，発達途上にある子どもにとって，慢性の病気 に罹患することは，なおいつそう大きな影響があると 思われる。動き回りたいときに運動制限があったり， 社会的経験を積むべき時期に限られた環境で安静を強 いられたりすることは, 病気が治癒した後にも影響を もたらすであろう。とくに，比較的早期に発症し，そ れが難治性であったり, 後の身体発達に大きなハンデ イキャップとなるような疾患に冒された人の意識や行 動にはなおのことであろう。

進行性筋ジストロフィー，気管支喘息，心臓疾患， 腎炎・ネフローゼなどの治癒の容易でない疾患に冒さ れた小児患者を日常的に観察していると，健常児に比 べ, 他者への依存, 社会的未成熟, あるいは困難な状 況での無関心な態度傾向などが目立つ(河野，19767)；

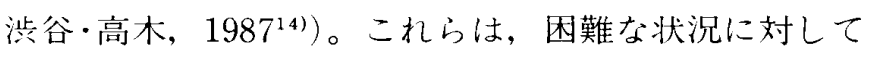
形成された一種の防衛機制と思われるが, 健全なもの とは言い難く、ひいては治療意欲に舟影響が出てくる ものと思われる。われわれは、こうした疾患のため長

*国立療羡所鈴鹿病院

**名古屋工業大学

***国立療養所中部病院
期大院を強いられている患児の療育指針を得る目的で， 彼らの行動特性の分析を進めているが, 本研究では, 特に自己意識の形成の側面に絞って検討を試みた。

ところで，自己意識は，自分自身を対象化した問い かけといってよい。そのような問いかけは多くは青年 期の特徵として位置づけられ，自己の発見と確立はそ の時期の重要な発達課題とされてきた（中西・鑪，

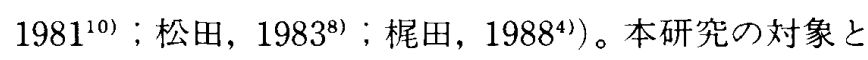
した難治性疾患の患児は，種々の重いンディキャッ プをもち，病院で療養生活を送っている。こうした生 活環境は, 彼らの自己の確立に大きな影響を与えると 思われる。彼らの自己意識の特徵をとらえることは， 自己の確立についての発達的な知見としうるとともに， 小児疾患者の療育指導についても重要な指針を与えて

くれると考えられる。

本研究では，質問紙による患児自身の評定に基づく 自己意識の分析を行ない, 疾患間の比較およびほぼ同 年㱓の健常者との比較を目的とする。なお，健常群に ついては，本質問紙による発達的差異导検討する。

\section{II. 方 法}

\section{1. 対}

調査対象者は, Table 1 に示す通りである。Duchenne 型進行性筋ジストロフィー (DMD) 男子は国立療養所 鈴鹿病院に，また気管支喘息男女は国立療養所中部病 
小笠原昭彦 - 甲村和三・宮崎光弘 - 牛田洋一 - 山内慎吾

Table 1 調查対象者

\begin{tabular}{|c|c|c|c|c|c|}
\hline & 男子 & 女子 & 合計 & 年齢（歳） & (平均) \\
\hline DMD群： & 35 例 & 0例 & 35例 & $10-24$ & $(17.1 \pm 3.80)$ \\
\hline 喘息群： & 25 & 16 & 41 & $12-18$ & $(14.5 \pm 1.90)$ \\
\hline 健常中学生群： & 229 & 262 & 491 & $12-14$ & $(12.6 \pm 0.57)$ \\
\hline 健常高校生群： & 276 & 216 & 492 & $15^{--} 17$ & $(15.1 \pm 0.29)$ \\
\hline 健常大学生群： & 196 & 181 & 377 & $18-25$ & $(19.2 \pm 1.08)$ \\
\hline
\end{tabular}

院に,それぞれ入院中である。比較対照群は, 愛知県 内の学校に在籍する健常者である。いずれも問題内容 を理解できないと思われる対象者は除いてある。

\section{2. 調查方法}

これら对象者に，50項目から成る質問紙を奏施した。 質問は，自己意識や日頃の心理的ストレス, さらに病 気に関するものなどである（項目作成には，市川・谷 口・甲村・寺本 $\left(1983^{2)}, 1984^{3)}\right)$ の研究を参考にし た)。なお，健常群には，病気によるストレス項目を除 いた42項目から成る質問紙を実施した。回答は，「全く そうである」「ややそうである」「どちらでもない」「や やそうではない」「全くそうではない」の５段階によっ て評定させた。

\section{III. 結 果}

\section{1. 結果の処理}

回答の評定段階の「全くそうである」に5点，「全く そうではない」に1点を与えて平均得点, 標準偏差の 算出などの計算処理を行った。

また，質問項目の分類を行なうために，青年期の自 己意識の発達の到達点として位置づけられる大学生群 の42項目の結果について因子分析を行った。計算処理 は，多変量解析ハンドブック・ソフト(HALBAU)（柳 井・高木・1986 ${ }^{15)}$ ) 利用して実施した。因子分析は， 標本相関係数行列を基に主因子解を求め, 固有值 1.0 以 上を基準に因子数を定め, Varimax 回転を実施し, 最 終因子解とした。その結果 5 因子が抽出できた(Table 2)。各因子の命名は, 便宜的に因子負荷量土 0.3 以上の 項目を参考とした。ただしここでの因子分析は, 項 目の分類を目的としたので，因子負荷量の低い項目も， ひとまず最大因子負荷量を基にどれかの因子に分類し た。各因子は，それに含まれる質問項目を参考に，I． 情緒性, II. 共感性, III, 对人関係, IV. 自己信頼感, V. 目標志向性と命名した。以下，各因子ごとに，平 均評定值によるプロフィールを描き，各群の特徵をみ ていく。なお, 平均年齢の近さを基準に, DMD 群の比
較対照群としては高校生群を, 喘息群の比較対照群と しては中学生群を選んだ。また，各群間の有意差娭定 には $\mathrm{t}$ 検定を用い，その結果はそれぞれの図の下部に 示してある。各質問の項目番号は, 患者群に奉施した ものの番号が示してある。

\section{2. 結果と考察}

以下，各因子ごとに結果圭述べるが，まず健常群に ついて自己意識の一般的な発達的様相を見たのちに， 疾患群の結果に触狄る。記述中，「」内，およU゙図の

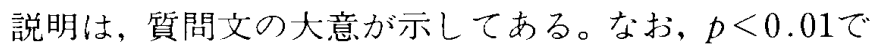
差のあった項目を有意差が認め放るとした。

1)「情緒性」（Fig. 1)

この因子は，不安，不満，気分の不安定などの感情 面における自己認識に関する質問項目である。大学生 群で著しい評定の偏向がみられたのは、「自分は弱い人 間だ」「空想が多い」「物事に敏感である」「生まれてこ なければよかった」「怒ると顔に出る」の各項目であっ た。中学生群, 高校生群と有意差の認められた項目を みると，「自分は弱い人間だ」「物事に敏感である」で は大学生群で，「空想が多い」は，中・高校生群でその 傾向が強かった。また、「生まれてこなければよかった」 では, 中学生群に比べ, 高校生群・大学生群で否定的 傾向が強かった。「身体の仕組みに興味」は, 中学生群 では興味がない傾向であったが, 高校生群, 大学生群 となるにつれ，「どちらでもない」に近くなっていた。 身体の成熟が著しい時期であるが，各群ともに積極的 な関心は抱いていなかった。大学生群で男女差が認め られた項目をみると，「生まれてこなければよかった」 で男子の否定的傾向が, 「物事に敏感である」で女子の 肯定傾向が, それぞれ強かった。健常群では, 不安定 な感情傾向は少ないようであるが，空想傾向や怒り・ イライラが顔に出やすいという感情統制がやや困難な 様子がうかがえる。「自分は弱い人間だ」という意識电 みられるが，生ま伅てきたことに対しては満足してい るようである。身体の仕組みについては，積極的な興 味はもっていなかった。年令が進むにつれ，空想傾向 
Table 2 健常大学生群42質問項目の因子分析結果

\begin{tabular}{|c|c|c|c|c|c|c|c|}
\hline & 質 問 項 目 & I & II & III & IV & $\mathrm{V}$ & $\mathrm{h}^{2}$ \\
\hline \multirow{15}{*}{ I } & 最近、不安に思うことが多い & -.684 & .011 & -.106 & -.136 & .023 & .498 \\
\hline & 最近、不満が多い & -.678 & .033 & -.058 & -.084 & .111 & .484 \\
\hline & 自分で自分のしたことがわからない & -.607 & .066 & -.013 & -.095 & .157 & .407 \\
\hline & イライラしたり腹を立てることが多い & -.603 & -.034 & -.053 & .100 & & .385 \\
\hline & ささいなことを気にする & -.507 & .062 & -.301 & .034 & -.054 & .355 \\
\hline & 自分を役に立たない人間だと思う & -.484 & -.123 & -.080 & -.3 & & .408 \\
\hline & 自分を弱い人間だと思う & -.475 & .089 & -.132 & -.321 & .133 & .372 \\
\hline & こうだったらよいのにという空想が多い & -.461 & -.022 & -.187 & .050 & .181 & .283 \\
\hline & 物事に敏感で他人の言動に傷つきやすい & -.445 & .174 & -.247 & .120 & -.158 & .329 \\
\hline & 生まれてこなければよかったと思う & -.435 & -.137 & .105 & -.269 & .055 & .294 \\
\hline & 人前では落ち着きを久くことが多い & -.353 & -.119 & -.290 & -.176 & .231 & .307 \\
\hline & 怒ったりイライラすると炎れが顔に出る & -.291 & .161 & .004 & .024 & .1 & .134 \\
\hline & 物事を感情的ではなく冷静に考え & .268 & -.217 & -.0 & .179 & -.2 & .195 \\
\hline & 夜は濅つきもよく、熟睡できる & .255 & .188 & -.1 & -.1 & & .156 \\
\hline & 自分の身体の仕組みに興吅 & -.202 & .144 & & & & .114 \\
\hline \multirow{10}{*}{ II } & 相手を思いあう人の愛こン & .092 & .551 & -.08 & -.00 & -.2 & .380 \\
\hline & 困っている人を見たウ & -.015 & .499 & .053 & .063 & -.1 & .287 \\
\hline & テレビなど悲しい場司 & -.118 & .496 & -.091 & -.023 & .0 & .278 \\
\hline & 神様・仏様などを信 & -.026 & .492 & -.14 & -.042 & .069 & .260 \\
\hline & 迷信や占いを信じやすい & -.252 & .449 & -.132 & .039 & .262 & .353 \\
\hline & 何でも打ち明けられる友人がいる & .087 & .406 & .139 & .160 & .01 & .217 \\
\hline & 泣きたくなるほどの悲しい経験がある & -.320 & .372 & -.0 & .061 & -.0 & .247 \\
\hline & この世で頼りになるのは自分だけだ & -.153 & -.295 & -.027 & .1 & .0 & .143 \\
\hline & 尊敬できる人がいる & .007 & .261 & .053 & .17 & -.1 & .127 \\
\hline & 物事の最後はメデタシで終わるべきだ & -.118 & .194 & & & & .091 \\
\hline \multirow{7}{*}{ III } & 人が私をどう思って & -.264 & .02 & -.5 & -.0 & & \\
\hline & もっと人に好かれる & 100 & .1 & -.5 & & .0 & .373 \\
\hline & 人前では自分をいい & -.113 & .05 & $-.4 t$ & -.04 & .1 & .253 \\
\hline & 異性に関心があり、仲 & .030 & .001 & -.352 & .245 & .1 & .203 \\
\hline & 他人が何を考えているかに興味がある & -.244 & .043 & -.347 & .099 & .0 & .196 \\
\hline & 初対面の人との話しは気が重くていやだ & -.193 & -.232 & -.3 & -.131 & -.1 & .222 \\
\hline & 自分は男（女）に生まれてよかった & .091 & .050 & -.270 & .152 & -.0 & .107 \\
\hline \multirow{4}{*}{ IV } & 今の自分が好きである & .230 & & -.053 & & & \\
\hline & 自分は頼りになるしっかりした人間だ & .290 & -.065 & .077 & .46 & -.1 & .324 \\
\hline & 生きがいとなる趣味で毎日充実している & .114 & .04 & 100 & .38 & -.1 & .211 \\
\hline & 負けず嫌いで負けると梅しくてならない & -.06 & .0 & -.1 & & .1 & .172 \\
\hline \multirow{9}{*}{$\mathrm{V}$} & 飽きっぼくて何事にも & -.224 & .006 & -.096 & -.087 & .554 & .374 \\
\hline & 何事もすぐドウデモイイ & -.139 & -.120 & -.040 & -.061 & & .328 \\
\hline & 自分の目標に向けていつも努力している & .097 & .150 & -.011 & .324 & -.373 & .276 \\
\hline & 将来より今が楽しければよい & -.014 & .040 & .143 & .222 & .333 & .193 \\
\hline & できるなら子供のままでいたい & -.256 & .117 & -.165 & .024 & .299 & .196 \\
\hline & もっと自分で努力することが大切だ & .100 & .185 & -.087 & -.114 & -.226 & .116 \\
\hline & & 4.11 & 2.13 & 1.88 & 1.68 & 1.62 & \\
\hline & 寄 与 率 & 36.00 & 18.65 & 16.48 & 14.67 & 14.20 & \\
\hline & 累積寄与率 & 36.00 & 54.65 & 71.13 & 85.80 & 100.00 & \\
\hline
\end{tabular}


は弱まり，「自分は弱い人間だ」あるいは「物事に敏感 だ」と意識するようになり，生まれてよかったと思う ようになっていた。

DMD 群は,「不満が多い」ささいなことを気にする」 「空想が多い」「生まれてこなければよかった」(否定 的傾向）「人前で落ち着きを欠く」「怒ると顔に出る」 とする傾向が目立つ。高校生群と比べると，「人前で落 ち着きを欠く」で高い平均評定点となっていた。健常 群と比べると, 感情の不安定さより, 感情の統制の面 で困難さを認めていた。DMDの身体状況からは, 感情 の不安定さが想定されるが，そうした傾向はうかがえ ない。難治性の疾患に冒されているが，身体の仕組み にも興味を示しているとは言えない。

喘息群は，「不安に思う」「不満が多い」「自分のこと がわからない」「イライラする」「自分は弱い人間だ」

「物事に敏感だ」「ささいなことを気にする」「空想が 多い」「人前で落ち着きを欠く」「怒ると顔に出る」と 評定する傾向が強かった。これらの項目のうち, 前 6 項目で中学生群との間に有意差が認められた。感情の 不安定さを認め, 空想傾问も強く，感情の統制が困難 だとする傾向もみられた。自分のことがわからない, 自分は弱い人間だという意識毛認めていた。これらの 評定結果から，喘息群は感情をコントロールできてい るとみておらず，自分のおかれた状況に対するいらだ ちとそれを制卸できないもどかしさを自覚していると 思われる。喘息に罹患しているため身体の仕組みには

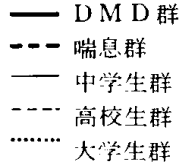

15 最近、不如に舁うことが多い

33 最近、不満が多い

14 自分で自分のことがわからない

27 イライラしたり腹を站てることが多い

13 ささいたとを氛にする

7 自分を役に胡たない人䦌だと照ら

1 自分を弱い人間だと思う

8 こうだったらよいのに上いう空想が多い

1 物事に覀感で他人の鬲動に傷つきやすい

20 生史れてこなければよかったと思う

1 人前では洛ち着き在久くことが多い

怒ったりイライラ寸るとそれが顔に泪る

10 物事を感情的ではなく冷静に考えられる

3 夜は裍つきもよく、熟睡できる

4 自分の身体の仕組みに與味がある

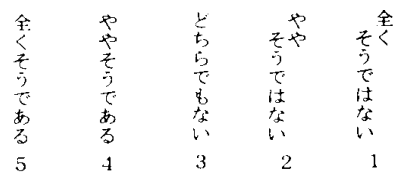

\begin{tabular}{|c|c|c|c|c|c|c|c|c|c|c|c|c|c|c|c|}
\hline 【平均評点間の有 & 意差 & 検定 & 結果 & & & $* * 2$ & $\mathrm{p}<$ & 60. & & & ** & 5 & 0.01 & & \\
\hline 項目番号 & 15 & 33 & 14 & 27 & 13 & 7 & 31 & 28 & 41 & 20 & 21 & 6 & 10 & 23 & 34 \\
\hline D M I 一喘息 & & & ** & & & & & & & & & & & & \\
\hline DM D－高校生 & & & & & & & & & & & $* * *$ & & & & \\
\hline 喘息 一中学生 & $* * *$ & $* * *$ & *** & $* * *$ & & $* *$ & & ** & & & & & & & \\
\hline
\end{tabular}

Fig. 1 「情緒性」の因子の平均評点プロフィール
興味があると予測したが, DMD 群と同様に興味は示し ていなかった。

DMD 群と喘息群との間で有意差が認められたのは, 「自分のことがわからない」の1項目であった。この 他，「物事に敏感である」など，感情の不安定さに関し た多くの項目で喘息群の方が平均評定点は高い傾向に あった。また「自分は弱い人間だ」あるいは「自分は 役に立たない」とする意識も喘息群の方が強い。「生ま れてこなければよかった」では，DMD 群の方が否定的 傾向が強かった。

\section{2 )「共感性」(Fig. 2)}

他人との感情の共有や交流に関する質問項目である。 大学生群は人の愛が大切」テレビなどで悲しくなる」

「神・仏を信じない」「何でも打ち明けられる友人がい る」「泣きたくなるほどの悲しい経験がある」「尊敬で きる人がいる」で高い平均評点を示していた。「愛が大 切」「テレビで悲しくなる」「何でも打ち明けられる友 人がいる」「泣きたいはどの経験がある」「尊敬できる 人がいる」では，中・高校生群より高くなっていな。 逆に，「神・仏を信じている」では，中学生群は中性的 な評価であるのに対し，高校生群，大学生群となるに つれ，「信じていない」とする傾向となった。また，中 学生では「この世で頼りは自分だけではない」として いたが, 高校生群・大学生群ではその傾向は弱まり, 中性的な評価となった。大学生群で男女差があった項 目をみると，「テレビで悲しくなる」「注きたいはどの 経験がある」で女子が，「神・仏を信じない」で男子 が, 高い評定をしていた。大学生群では，概して豊か な共感性を示していた。こうした傾向は，年令ととも

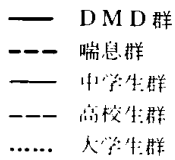

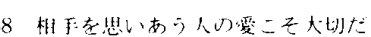

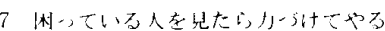

32 テレビなど惎しい埸田で热しくなる

10 神㥞・仏椂な占老们している

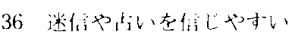

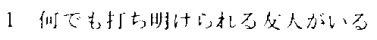

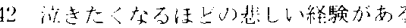

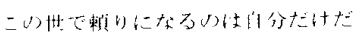

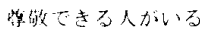

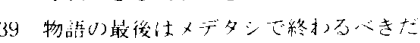

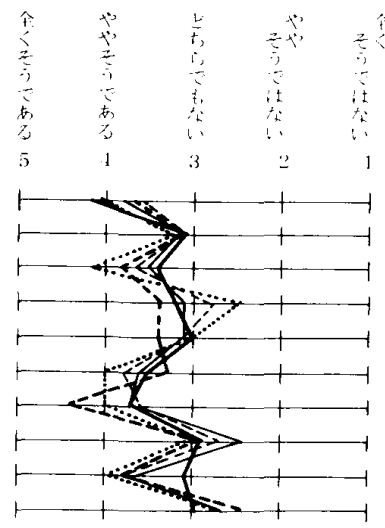

【平均評点間の有意差検定結果】 $* * * p<0.001 \quad * * p<0.01$

\begin{tabular}{|c|c|c|c|c|c|c|c|c|c|}
\hline 項目番号 & $38 \quad 37$ & 32 & 40 & 36 & 1 & 42 & 11 & 2 & 39 \\
\hline D M D 一喘息 & & & & & & *** & & & \\
\hline DM D - 高校生 & & & & & & & & **** & \\
\hline 喘息 一中学生 & & & & & & *** & ** & & \\
\hline
\end{tabular}

Fig. $2 「$ 共感性」因子の平均評点プロフィール 
に強くなっていくようである。ただ，年令が進むにつ れ，「神・仏を信じない」「この世で頼りは自分だけ」 とする傾向が強くなり，他者への依存傾向は弱くなっ ていた。

$\mathrm{DMD}$ 群では,「人の愛が大切」「何でも打ち明けられ る友人がいる」「泣きたいはどの悲しい経験がある」で 平均評点の偏向が目立った。高校生群と比べると,「尊 敬できる人がいる」で有意に低くなっていた。また，

「人の愛が大切」とする傾向がみられた。

喘息群では,「人の愛が大切」「テレビで悲しくなる」 「泣きたいほどの経験がある」「尊敬できる人がいる」 「物語の最後はメデタシでなくともよい」において評 定の偏りが著しかった。中学生群に比べ,「泣きたいほ どの悲しい経験」を有意に強く訴えていた。中学生群 で「この世で頼りは自分だけでない」とする傾向が強 かった。喘息群は, 他者との感情の共有や交流がなさ れていると自己評定しているようである。とくに，悲 哀体験の訴之は，非常に強くなっていた。また，「神・ 仏を信じる」「迷信・占いを信じやすい」という傾向も みられる。

DMD 群と喘息群とを比べると, 喘息群の方が「泣き たいはどの経験がある」と有意に高く評定していた。

「人の愛が大切」ではDMD 群の方が高く，「尊敬でき る人がいる」「物語の最後はメデタシでなくてよい」で は喘息群の方が高く評定する傾向がみられた。また， 喘息群の方が「神・仏を信じる」「迷信・占いを信じや 寸い」傾向もうかがわれた。

$3) 「$ 対人関係」(Fig. 3)

对人関係の保持，あるいは改善についての質問項目 である。大学生群は，「人がどう思うか気になる」「も つと人に好かれたい」「人前でいい子に見せたい」「異

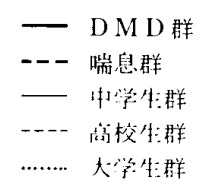

5 人が私をよう焽っているが们なる 6 む一上人に好加る上うになりたい

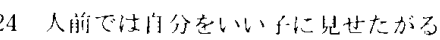

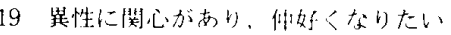

35 他人が仰老古丈ているかに睓味がある

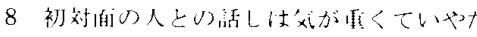

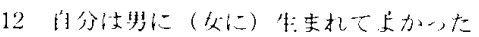

【平均評点間の有意差検定結果】 $* * * p<0.00$ 】 **p<0.01

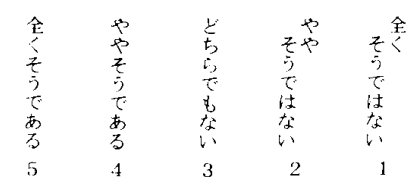

\begin{tabular}{|c|c|c|c|c|c|c|c|}
\hline 項目番号 & 5 & 16 & 24 & 19 & 35 & 8 & 12 \\
\hline D M D 一喘意 & & & & & & & \\
\hline D M D -高校生 & & & ** & & & $* * *$ & \\
\hline 喘息 一中学生 & & & & *A* & ** & & \\
\hline
\end{tabular}

Fig. 3 「対人関係」因子の平均評点プロフィール
性に関心あり」「他人の考えに興味がある」「性別に満 足」のすべての項目で平均評点が 4 点前後と高くなっ ていた。中学生・高校生群でも,「人がどう思うか気に なる」「もつと人に好かれたい」「性別に满足」では， 平均評点の偏りが著しかった。これら健常群の結果の うち，「性別に満足」では 3 群とも有意に男子の方が満 足感が高かった。また，中学生群では，女子が「もっ と人に好かれたい」とする傾向が強かった。大学生群 では，男子の方が「異性に関心がある」としていた。 健常群では，一般にこの面での積極性がうかがわれた。 とくに大学生群でその傾向が顕著である。「性別への満 足」「異性入の関心」は男子の方が強かった。

DMD 群をみると, 概ね健常者と同様の傾向であった が，健常群はどの積極性はみられなかった。高校生群 と比べて差があったのは「人前でいい子に見せたがら ない」「初好て人と話すのは気が重い」と評定してい た点である。また，DMD は原則として男子だけに発症 する疾患であるが，「男に生まれてよかった」と評して いた点は注目される。

喘息群でも，健常群と同様な傾向である。「人がどう 思うか気になる」「もっと人に好かれたい」「異性に関 心あり」「他人の考えに興味あり」「性別に満足」と評 定していた。中学生群に比べ，「異性への関心」「他人 の考えに興味あり」で高い評点が認められた。他者へ の関心は強いようであり，とくに「人がどう思うか気 になる」は平均評点が电っと毛高く，人の目を気にし ているようである。

DMD 群と喘息群との間には有意差の認められる項目 はなかったが，喘息群の方が「人がどう思うか気にな る」「人に好かれたい」「他人の考えに興味がある」と する傾向がみられた。一方，DMD 群の方が「性別に満 足する」傾向がやや強かった。

4 ）「自己信頼感」(Fig. 4)

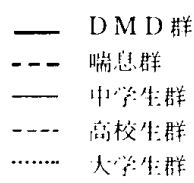

26 今心自分が好きである

18 内分は賴りになるし一かりした人間た

9 特きがいとなる趣味で辞时允起している

30 织计才゙兼いで偩ける上悔しくてならない

\begin{tabular}{ccccc} 
【平均評点間の有意差検定結果】 \\
\hline 項目番号 & 26 & 18 & 9 & 30 \\
\hline DMD - 喘息 & & & & \\
DMD - 高校生 & & $* *$ & & \\
喘息 一中学生 & & & & $* *$ \\
\hline
\end{tabular}

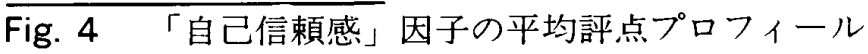


自分を信頼するか，あるいは好きであるかといった 項目である。大学生群では, 自分自身は，好きでも嫌 いでもなく、「自分は頼りにならない」とし，やや「充 実感に欠け」、「負けず嫌いである」とする傾向がうか がえる。概放各群とも似た評定傾向であった。大学生 群では，女子の方が有意に「自分は頼りにならない」 としていた。DMD 群は, 高校生群に比べより「頼りに ならない」として抢り, 喘息群は中学生群と比へ，有 意に「毎日充実していない」と評定していた。また， 喘息群では、「頼りにならない」とする傾向もみられ た。DMD 群と喘息群の間には有意差はなかった。

5 )「目標志向性」(Fig. 5)

目標に向けての努力や生き方に関する項目である。 この因子でも，一部の項目をのぞいて，各群の評定傾 向は似ていた。各群とも，「努力することが大切」と強 く思っている他は，どの項目も「どちらでもない」に 近くなっていた。「努力が大切」では, 大学生群が高校 生群に比べ強く思っていた。子細にみると,「目標に向 け努力している」では, 中学生群が高校生群・大学生 群よりその傾向が強かった。逆に,「何事でもすぐドウ デモイイヤと思う」では, 高校生群・大学生群の方が 高くなっていた。「将来より今が楽しければよい」で は, 高校生群が大学生群より否定的傾向がより強かっ た。大学生に比べ中・高校生で「子供でいたい」と評 定する傾向がみられた。努力の必要性は健常各群とも 認識しているが，実際に努力をし，しかも投げやりで ないという意識は中学生群で強いようである。

DMD 群は，健常群とほぼ同様の傾向であった。高校 生群との間には, 有意差は認められなっかたが,「将来 より今が楽しければよい」では，他の 4 群とは逆にや や肯定的な評定結果であった。

$$
\begin{aligned}
& \text { - D M D) 样 }
\end{aligned}
$$

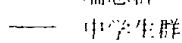

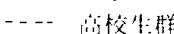

$$
\begin{aligned}
& \text { ……… 大 }
\end{aligned}
$$

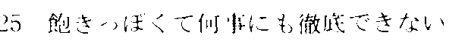

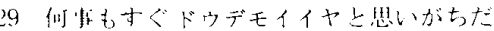

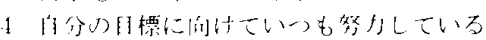
㥒长上り令が楽しい好ば上い

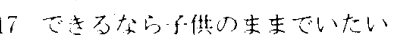

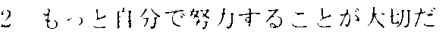

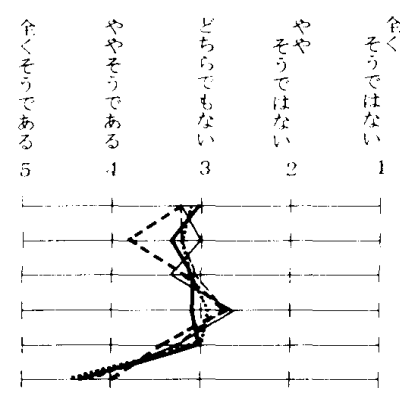

\begin{tabular}{|c|c|c|c|c|c|c|}
\hline 【平均評点間の有 & 意差 & 検定 & & & & $* * *$ \\
\hline 項目番号 & 25 & 29 & 4 & 3 & 17 & 22 \\
\hline \multicolumn{7}{|l|}{ DM D －喘息 } \\
\hline \multicolumn{7}{|l|}{ DMD 高校生 } \\
\hline 喘急 一中\%物 & & *** & & & & \\
\hline
\end{tabular}

Fig. $5 「$ 目標指向性」因子の平均評点プロフィール
喘息群は，「何事もすぐドウデモイイヤと思う」で高 い平均評点を示し，中学生群との間に有意差があった。 また、「子供でいたい」でも他の群に比べやや高い值と なっていた。DMD 群との間には有意差はなかったが, 投げやりな傾向は喘息群の方が強かった。

6)「患者群にのみ適応したその他の項目」(Fig. 6)

患者群にのみ実施した，病気に関する項目をみると， 喘息群の方が強く「自分が病気で家族にすまない」と 思っていた。また，喘息群では「病気になった自分が 情けない」とする傾向が，DMD 群では「他人の介護を 好まない傾向がみられた。DMD 群では，身体不自由 のため，他者の介護により日常生活が成り立っている ところが大きいが，患児自身はこれを肯定している訳 ではないようである。喘息群では，病気に対する「罪 悪感」といったものが強いようである。両群とも，「病 気でなければ健康な子に負けない」病気は気の持ちよ う」「入院生活は退屈」と評定していた。「健康な子に 負けない」という項目での「病気」は自分自身の疾患 ととらえていると思われるが「気の持ちよう」では「病 気」在自分自身の疾患というよりは，病気一般とみて いるのではないかと思われる。

\section{IV. 討 論}

本研究は諸種の疾患により幼児期から心身にハンデ イキャップを負っている小児諸疾患児の自己意識の発 達の様相を調へ，発達上の問題点を探ろうとする試み である。すでに述べたように，幼児期からの病気は性 格形成や行動習慣形成にも大きな影響を与之ると予想 される。小児疾患者の心理特性については, DMD や喘 息ではいくつかみられるが(河野, 19767)；Maurer, 19659
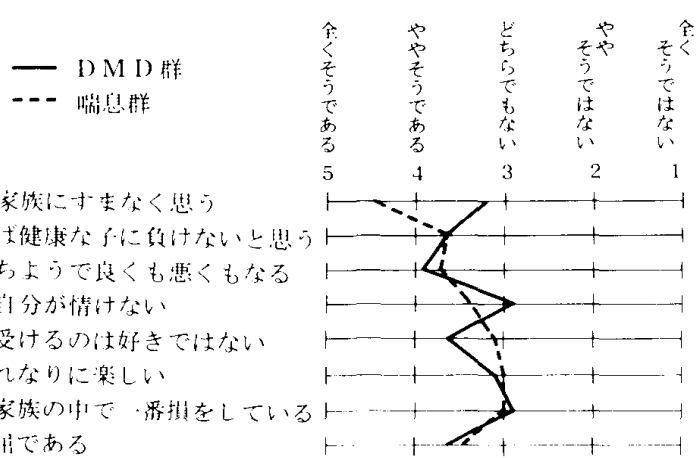

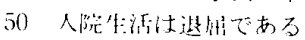

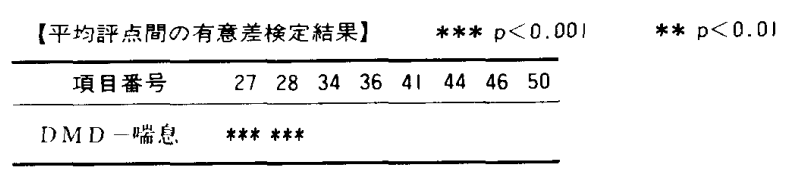

Fig. 6 患者群にのみ実施した項目の 平均評点プロフィール 
; Neuhaus，1958 $\left.8^{111}\right)$ ，われわれが行なったような調查 的研究は少ない。わずかに喘息児からみた父親像に関 するものが散見される程度である(安達・安浪・岡田・ 豊島・渋谷, $\left.1988^{11}\right)$ 。

本報告では諸種の疾患のうち，例数の多かった小児 喘息と進行性筋ジストロフィ一の疾患児の資料につい てとりあえずまとめることとした。小児喘息は周知の ように，気管支の狭窄のために生ずる，高度の喘鳴と 呼吸困難発作である。成因は，アレルギーが最も重要 視されるが，多分に心身症的疾患である。また，DMD は筋肉の萎縮々筋力低下を主症状とする進行性の疾患 である。その原因は未だ不明であり治療法も確立され ておらず，病気の予後からすれば小児喘息に比べると はるかに樑刻度が高い身体性の疾患である。本研究で は，これら 2 疾患者の自己評定に基づく自己意識の発 達について疾患群間の比較とともに, 患児と健常な中 学・高校・大学生の自己意識発澾傾向と比較してみた。 以下，結果を要約しながらの全体的考察を試みること としたい。

大学生群は, 青年期の自己意識の到達点とほぼ位置 づけられよう。今回の結果では, 感情統制の面でやや 困難さがうかが之, 空想傾向もみられるが，感情は概 して安定しており，他者への共感性や対人関係の積極 さ毛みられた。また，自分に対する信頼感にはやや久 け，目標志向はみられるが，実際の努力へは結びつい ていないようであった。発達的にみると，感情面では 著しい評定の偏りには至らないが，やや不安定な方向 へ変化し，自分は弱い人間だとか物事に敏感だという 意識が強くなっていくようである。青年期は，自我の 発達や身体成熟にと毛ない，両親などから自立し，自 分の生き方を決定していくことを求如的年代であ る。これは，自信や希望を与えるとともに，自己の危 機や不安を体験させるものでもある。(加藤, $\left.1987^{5)}\right)$ 。こうした青年期の特質が，上述の感情面での やや不安定な方向への変化に現れているものと考之ら れる。感情統制面ではどの年秢でも，怒ると顔に出や すいなどやや統制困難な様子がうかがわれる。空想傾 向は，年柃とともに減少していく。他者との感情の共 有・交流も豊かになる一方で他者への依存傾向は減少 していた。対人関係の面でも，年齢とともに積極的に なり，とくに他者の目を気にするようになって行くよ うであった。「異性への関心」「性別に満足」は男子で 強かった。自己に対子る信頼感については，年齢によ る大きな変化はなかったか概して自分を頼りになると はみていなかった。目標に向けての努力の重要性は,
ぞの年齢でも認識されていたが, 高校生・大学生群で は実際の努力にあまり結びついておらず，投げやりな 傾向もうかがえた。中・高校生では刹那的な態度に否 定的であるとともに，子供でいたいとする傾向もみら れた。

DMD 群では, 身体状況から想定されるほどの感情の 不安定さは示されなかった。これまでの研究でも DMD の情緒的反応の少なさが指摘されているが(河野, $1976^{7}$; 甲村・小笠原, $\left.1988^{6}\right)$, 今回の結果毛同様であ った。 DMD 群は，对人関係の面での消極さを除くと， 健常群に比べ著しい特徵はみられず, 自己意識の上で の問題点はみられなかった。

これに対して, 喘息群では感情の不安定・統制困難 あるいは楚想傾向を認めるとともに，悲哀体験の訴之， 神仏・迷信などへの依存, 他人の目への敏感足, 投げ やりな傾向が目立つ自己評定結果であった。病気に関 する項目をみても，病気による「罪悪感」といった気 持ちを毛っているようでもあった。こうした結果から みると，喘息児は，自分の扮かれた状況に対しての不 満，いらだちといった感情の不安定さとそれらを自分 でコントロールできないもどかしさを自覚しているよ うである。こうした点が, 喘息児での自己意識形成の 上での問題点であると考えられる。

今回の結果からは，身体的にははるかに重症度の高 いと考之られるDMD 群においてよりも喘息群で自己 意識形成の上で問題点が多いことが明らかにされた。 このような評定傾向が喘息群に特有のものかどうかは, 今後さらに他の疾患群との比較によって明らかにする 必要がある。しかし，岡 $\left(1988 \mathrm{a}^{12)}\right)$ は，子どもの生活 目標は, 様々な種類の自己認知によって規定され，虚 弱児は健康児に比べ自己の諸領域を低く認知している と報告している。今回明らかになった喘息群の自己意 識の特徵は, 治療意欲などを含めた彼らの生活面にも 大きな影響を持っていると考之られ，療育指導上留意 すべき点であろう。また，渋谷・高木 $\left(1987^{14)}\right)$ は，喘 息児の性格について, 小学校低学年では対照群と差が なかったが, 高学年では種々の性格の歪みが現れるこ とを指摘している。今回, 対象としなかった小学生段 階からの自己意識形成の問題导今後検討していくこと が必要となろう。

DMD 群では, 自己意識形成の上での大きな問題点は 認められなかった。これまで, DMDの情緒的反応の少 なさは apathy 的適応機制によるとの指摘があったが(河 野，197677), 「感じ方」が違うのか, 「表現の仕方」が 違うのか明らかでなかった。岡 $\left(1988 \mathrm{~b}^{13)}\right)$ は，健康度 
が低いほど心理的問題を感じやすいことを指摘してい る。DMDは，普段の生活では身体面の不自由さは大き いが，「健康」という面では常に問題がある訳ではな い。DMDの情緒的反応については，今後こうした知見 も考慮に入れて検討を進めるべきであろう。

岡 $\left(1988 \mathrm{~b}^{13)}\right)$ は，また，心理的困難への対処行動の 努力を支える要因として教師，友人，親などの身近な 対人的環境が重要であることを指摘している。こうし た観点から，療育にたずさわる職員や両親が患児をど うとらえているかを理解しておくことは，小児慢性疾 患児の療育に際して重要な意味をもつとい之る。この 点に関して，喘息児の場合について改めて報告したい。

\section{謝 辞}

本研究を実施するにあたり，有益な御示唆と御協力 をいただきました国立療養所中部病院小児科医長・上 田雅乃先生に深甚な謝意を表します。

\section{文 献}

1）安達邦子・安浪 純・岡田正幸・豊島協一郎・渋 谷信治（1988）：気管支喘息児からみた父親像. 小児保健研究, 47 ( 3 )，343-349.

2 ）市川典義·谷口 茂·甲村和三・寺本一美（1984）: 現代学生のライフスタイルに関する総合的研究 ( I ) 一自我発達と価值観について一。名古屋工 業大学学報, $35,17-26$.

3 ）市川典義·谷口 茂·甲村和三·寺本一美 (1983): 現代学生のライフスタイルに関する総合的研究 (II) - 自我発達·価値観に関する因子分析的検 討一。名古屋工業大学学報, $36,1-7$.

4) 梶田瑴一(1988)：自己意識の心理学[第 2 版〕. 東 京大学出版会.

5 ) 加藤隆勝 (1987)：青年期の意識構造一その変容と
多様化一。誠信書房.

6 ）甲村和三・小笠原昭彦（1988）：Duchenne 型筋シ ストロフィー患者の「時間」㧍よび「将来」に 関するイメージの分析．心身医学，28，317一 323.

7 ) 河野慶三 (1976)：筋ジストロフィ一患者の心理特 性とそのCare．国立療養所鈴鹿病院、鈴鹿.

8 ）松田 惺 (1983)：「自己意識」.三宅和夫・村井 潤一・波多野誼余夫・高橋恵子（編）波多野・ 依田児童心理学ハンドブック，金子書房．640664 .

9) Maurer, E. (1965) : The child with asthma : an assessment of the relative importance of emotional factors in asthma. Journal of Asthma Research, 3 (1), 25-79.

10）中西信男·鏬幹八郎 (1981)：自我·自己（有斐閣 双書 · 心理学 10$)$. 有斐閣.

11) Neuhaus, E. C. (1958) : A personality study of asthmatic and cardiac children. Psychosomatic Medicine, 20 (3), 181-186

12）岡茂(1988 a )：身体虚弱児の自己認知と生活目 標に関する研究一一般校における虚弱児を対象 として一。特殊教育学研究, $26(1), 23-30$.

13）岡 茂 $(1988 \mathrm{~b})$ : 病虚弱児のもつ心理的問題と対 処行動に関玄る研究一対処行動の規定要因を中 心として一。特殊教育学研究, $26(3), 23-$ 30 .

14）渋谷信治・高木俊一郎（1987）：喘息児の性格傾向. 心身医学，27，502-509.

15）柳井晴夫・高木廣文（1986）：多変量解析ハンドブ ック. 現代数学社.

— 1989. 3. 6. 受稿, 1989. 8. 26. 受理 - 
付表 調査に用いた質問紙（フェイスシートを除く）

1.私には何でも打ち明けられる友人がいる

2.私には軎敬できる人がいる

3、人生は将来よりも今が楽りければよいと思う

4. 私は自分の目槙に问けて、つも努力している

5.人が私のニとをどう思っているか気になる

6.私は怒ったり、イライラしたりするととれがすぐ 顔にでる

7. 私は自分を役に立たない人井だと思っている

8. 初めて会った人と話をするのは武がくて重くだ

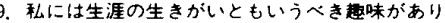

每日が充実している

10、私は物事を感情に流されることなく冷埩に考える ことができる

11、結局、この世で頼りになるのは自分だけだと思う

12. 私は自分が男に(あなたが女性なら女に)生まれて よかったと思う

13. 私はささいなことを䌾にする方である

14、私は、時夕、自分で自分のことがわからなくなる

15、私は最近不安に思うことが多い

16。私はもっと入に好かれるようになりたい

17. 私はできるなら、子供でいたい(いたかった

18. 私は自分を頼りになるしっかりした人间だと思う

19、私は異性に対して関心があり、できれば女の子と（男の子と） 仲好くなりたいと思う

20. 私は自分がこの世に生まれてこなければよかった と思うことがある

21. 私は人前ではおどおどする(落ち着きを欠く ことが多い

22.私は自分を良くするにはもっと自分で努力する ことが大切だ思っている

23. 私は夜は摜つきもよく、いつも勲睡できる

24、私は人前では自分を“いい子”に見せたがる㖽向 がある

25. 私は能きつはくて何事にも使底してできない

26、私はやっばり今の自分が好きである

27、私は自分が病文になり家薄にすまないと思っている

28. 私は自分が病気でなければ健康な子に負けない 自信がある

29. 私は、最近、イライラしたり嗄を立てることが多い

30 私は、最近、こうだったらよいのにと空想したり して過こすことが多い

31. 私は何事にかかからす、すぐ・ドウデモイイヤ と思いがちである

32. 私は貣けず搛いであり、他人と競争して負けると 悔しくて仕方がない

33. 私は自分を弱い人間たと思う

34. 私は病曼というものは文の持ちようで良くも 悪くもなるものだと思う

35. テレピや映画で悲しい場面を見るとつられて自分も 悲しくなってしまう

36. 私は病気になった自分を博けなく思っている

37. 私は、最近、自分でも不满が多いように思う

38. 私は自分の体の仕組みについて垻味がある

39.私は他人が何を考えているかに興味がある

40、私は迷信や占いを信じやすいすである

41、私は他人の介樭を受けるのは本当をいえば 好きではない

42.私は困っている人を見たらすく声をかけたり カว゙けたりする方である

43. この世で一番大切なことは互いに助け合ったり 相手を思いあう人の爱だと思う

44.入院生活はそれなりに結践楽しい

45.私は物晤の最後がメデタシメデタシで終わらないと をやみに腰がたつ方である

46. 病弐になった自分は家族の中では一翻提をしている と思う

47、私は神棒や仏楎（あるいは特定の家教）を 信している

48. 私は物事に教感な方であり、他人の要轩に 骤つきやすいちだと思う

49. 私は泣きたくなるほど悲しいと思ったことがある

50. 入院生活は退屈である 


\title{
Analysis of Self-Consciousness Using Self-Rating Scales in Children with Duchenne Progressive Muscular Dystrophy and Asthma
}

\author{
Akihiko Ogasawara*, Kazumi Kohmura**, Mitsuhiro MiYaZaki***, \\ Youichi USHIDA***, and Shingo YAMAUCHI*** \\ * Suzuka Byoin National Sanatorium (Suzuka-Shi, 513) \\ ** Nagoya Institute of Technology (Nagoya-Shi, 464) \\ ***Chuubu Byoin National Sanatorium (Ohbu-Shi, 474)
}

The present study was conducted to clarify the developmental characteristics of self-consciousness in children with various chronic diseases.

The self-consciousness of children with Duchenne progressive muscular dystrophy (DMD) and asthma was studied, using a self-rating questionnaire. The questionnaire consisted of 50 questions concerning self-consciousness, mental stresses, and attitude toward their disease. The questionnaire was administered to 35 males with Duchenne progressive muscular dystrophy (DMD), 10 to 24 years of age, and 41 youth with asthma, both males and females, 12 to 18 years of age. The control group was 1,360 junior and senior high school students and college undergraduates, 12 to 25 years of age. The control group was administered only 42 of the questions, omitting those on attitude toward one's disease.

The results were as follows:

1. As a result of a factor analysis based on the college students' data, five factors were extracted. They were named (a)emotionality,(b)sympathy,(c)human relations,(d)self-reliance, and(e)intention toward a goal.

2 . The group of college students is considered to have accomplished the development of their selfconsciousness in their adolescence. In general, they were emotionally stable. Also, they had sympathy toward other people and a positive attitude in human relations. However, they had some difficulty in controlling their emotions, and a little lack of reliance on themselves. Although they had an intention to attain their goals, it was not connected to their actual effort.

3 . The control group had some difficulty in the control of their emotions in general. They were slightly unstable in their emotions, and more sympathetic and more positive in their human relations as a function of age.

4 . Subjects with Duchenne progressive muscular dystrophy (DMD) showed similar tendencies to the control group, except that they lacked positivity in human relations. In addition, they had more difficulty in controlling their emotions, compared to the group of senior high school students. The subjects with Duchenne progressive muscular dystrophy (DMD) did not show the unstable emotions that we had expected, given their physically severe condition.

5 . The subjects with asthma were emotionally unstable and had difficulty in controlling their emotions. Also, they complained of "sad experiences". In addition, they showed a dependency upon God, Buddha, or superstition, sensitivity to other people's looks, and negligent attitudes. The subjects with asthma seemed to be aware of their dissatisfaction with and irritation about their circumstances, and impatient about their lack of control of their feelings.

Key Words : self-consciousness, self-rating, youth with Duchenne muscular dystrophy, youth with asthma 